\title{
Post-populism in Zambia: Michael Sata's rise, demise and legacy
}

\author{
Alastair Fraser \\ SOAS University of London, UK
}

\begin{abstract}
Models explaining populism as a policy response to the interests of the urban poor struggle to understand the instability of populist mobilisations. A focus on political theatre is more helpful. This article extends the debate on populist performance, showing how populists typically do not produce rehearsed performances to passive audiences. In drawing 'the people' on stage they are forced to improvise. As a result, populist performances are rarely sustained. The article describes the Zambian Patriotic Front's (PF) theatrical insurrection in 2006 and its evolution over the next decade. The PF's populist aspect had faded by 2008 and gradually disappeared in parallel with its leader Michael Sata's ill-health and eventual death in 2014. The party was nonetheless electorally successful. The article accounts for this evolution and describes a 'post-populist' legacy featuring hyperpartisanship, violence and authoritarianism. Intolerance was justified in the populist moment as a reflection of anger at inequality; it now floats free of any programme.
\end{abstract}

Keywords

Elections, populism, political theatre, Laclau, Zambia, Sata, Patriotic Front

\section{Introduction}

This article both contributes to the thin theoretic literature on 'post-populism' and develops an illustrative case. It discusses the explosive arrival of the Patriotic Front (PF) on the Zambian electoral scene in 2006 and the party's subsequent evolution. It examines how the PF has been framed as populist by authors emphasising the policy orientation of rational actors operating in a political marketplace, and argues that this framing stretches the concept beyond usefulness. It suggests that the PF's 2006 campaign can more sensibly be described as populist on the basis that it used political theatre to construct antagonistic social identities. It thus extends Benjamin Moffitt's (2016) analysis of populism as political theatre by showing that populism often draws its audience, 'the people' on stage. The resulting necessary improvisation of a leader's performance can sharpen contradictions inherent in populist mobilisations: theatrical illusions are difficult to sustain. This helps explain the party's inability to institutionalise, and its evolution from populism to authoritarianism. The article also highlights the extent to which the PF's populism became untenable because it was bound up with the energetic and confrontational persona of the party's founder, Michael Sata, a performance he struggled to sustain.

While Sata won the presidency in 2011, and the PF retained power under Edgar Lungu, the article suggests that the party's populism mellowed immediately after the 2006 campaign and then faded and disappeared in parallel with Sata's ill-health and eventual death in 2014. This raises two questions: how did the party increase its vote share even as its populism faded, and what does this tell us about what comes after populist moments? The article directs attention to the ways Zambian political celebrities mobilise clientelist networks, which frequently switch parties en masse. These 
collective defections render implausible accounts of parties as outgrowths of citizens' programmatic preferences, economic interests or ethnic identities. As the PF took over urban representative structures from 2006, and then won the presidency in 2011, contestation over the spoils of power generated resentments, defections and violent confrontations within and between parties. This turbulence reflected little more than the clashing ambitions of a set of political chameleons. The article concludes that Zambia now experiences a 'post-populist' legacy. Hyper-partisanship and violence, connected in the populist moment to unmet social needs, remain. An optimistic, futureoriented project to meet those needs has dissipated, leaving popular cynicism and apathy and an insecure, authoritarian ruling party.

\section{A sketch of the PF's history}

Independent since 1964, Zambia's economy has been dominated by the export of a single commodity (copper), the price of which is unstable. A debt crisis in the 1980s empowered Zambia's donors, whose influence supported domestic pressures for democratisation and economic liberalisation. After the peaceful departure of founding president Kenneth Kaunda and his United National Independence Party (UNIP) in 1991, the Movement for Multiparty Democracy (MMD) failed in its first decade to deliver prosperity. Frederick Chiluba, the MMD's trade unionist leader, clung to power until 2001 by undermining democratic competition, demobilising the party's urban and labour support base and managing clientelist networks centred on the presidency.

Chiluba met his political end in the popular defeat of his bid for an unconstitutional third term. When Levy Mwanawasa was appointed as Chiluba's successor, Michael Sata - a veteran politician with trade unionist roots similar to Chiluba's - felt overlooked and left the MMD. He launched his own party, the PF, just before the 2001 elections. With little time to organise, it won few votes.

Mwanawasa's presidency saw comparatively fair multi-party competition. A liberalised media enabled diverse voices to be heard and increasing mobile phone ownership allowed politicians to build an unmediated dialogue with voters through call-in radio shows (Simutanyi et al., 2015). Nonetheless, it was unclear that opposition parties could make much of these openings. Most challengers to the MMD since 1991 had been 'big men' who funded their own parties and used patronage rather than a programmatic appeal to stitch together regional voting blocs (Posner, 2005). Debt dependence also played a role in Zambia's 'choiceless democracy' as opposition parties internalised IMF and World Bank policy preferences (Mkandawire, 1999). This is not to say that the MMD's opponents would, without donor incentives, have been radical: the most significant leader, Anderson Mazoka of the United Party for National Development (UPND), was a former executive of mining multinational Anglo-American. Indeed, in the post-Cold War world, ideologicallycoherent, mass-based, democratic parties are in short supply globally. As Peter Mair puts it, politics had been 'stripped of its popular component' leaving 'democracy without a demos', in which, in terms of voters' attitudes towards their representatives, the 'dividing line between indifference and hostility is not always very pronounced' (2006: 25). Zambia in the mid-2000s was in this sense ripe for change: its economy was depressed and unequal, its institutions and media left space for opposition, but a technocratic consensus reigned and no party or movement seemed capable of channelling popular frustrations.

Shortly before the 2006 election, three factors shifted. In April 2005, Zambia satisfied its creditors' demands and was granted US\$3.9 billion of debt relief, weakening donors' grip. A concurrent upswing in global copper prices re-awakened Zambia's economy but windfall profits for mining multinationals drew attention to the unfavourable terms of the industry's privatisation (Fraser and Lungu, 2007). Thirdly, in May 2006, UPND leader Mazoka died. His replacement, Hakainde Hichilema (like Mazoka, an ethnic Tonga businessman, known for his proximity to international capital) was chosen over Mazoka's deputy Sakwiba Sikota, an ethnic Lozi. The UPND was labelled 
as a party captured by Tonga interests. In a country in which 'tribalism' is taboo, a gap opened for an alternative representative of the anti-MMD mood.

Sata stepped into this context, emphasising a range of problems including urban disorder, inequality, precarious employment in the mines, corruption and the dependence of Mwanawasa's administration on Western - and, increasingly, Chinese - sponsorship. The PF attracted a huge urban vote and almost won power in the 2006 elections. The pattern repeated in a 2008 presidential by-election after Mwanawasa's death. Then in 2011, Sata finally won enough rural votes to add to his dominance of the urban electorate and take power. However, the PF had not won a parliamentary majority and, within months, adopted familiar methods to buy off opposition MPs.

The sense of an administration struggling for control was exacerbated by the fact that, since 2008, Sata had been visibly ailing. As president, he disappeared as a public figure, seeming to have little energy to pursue a transformative agenda, let alone manage debilitating factionalism within his party. Sata died in office in late 2014. Violence surrounded the brutal competition to become the PF's candidate to contest the resulting 2015 presidential by-election, revealing the limited institutionalisation of a party run as a vehicle for one man. Edgar Lungu took the PF nomination, narrowly defeated Hichilema's UPND (the MMD imploded) and saw through the last 18 months of Sata's term. The parties repeated similar vote shares in the August 2016 tripartite elections, which were marred by unprecedented political violence and repression of the independent media. An unsuccessful petition to Zambia's Constitutional Court focused attention on the suspiciously narrow achievement of a new requirement to secure more than $50 \%$ of the vote to avoid a run-off (Fraser, 2016). The administration then attracted international condemnation when it responded to the opposition leader's refusal to accept Lungu's legitimacy by incarcerating Hichilema on treason charges.

The emergence of the UPND in 2001, of the PF after 2006, the implosion of the MMD after 2011, and the resultant boiling down of a fragmented party system into close head-to-head confrontations between the PF and UPND in 2015 and 2016 can be seen in Figure 1 below.

\section{Rational actor models}

Since 2006 the PF has been categorised in a range of articles and books as 'populist' or 'ethnopopulist' and contrasted to the MMD (seen variously as liberal, technocratic and as an incumbent 'catch-all' party), and the UPND (sometimes read as ethno-regional, sometimes as liberal). Most authors seek to explain the rise of the PF using a methodologically individualist model of politics, involving an electoral marketplace in which power-seeking politicians respond 'rationally' to public demand with promises to supply policy goods.

Danielle Resnick (2013) identifies urbanisation and unemployment as the fuel for Sata's rise. Inadequate infrastructure forced urban dwellers to take expensive journeys from under-serviced residential areas to insecure work in the informal sector. The difficulty of securing licenses to 


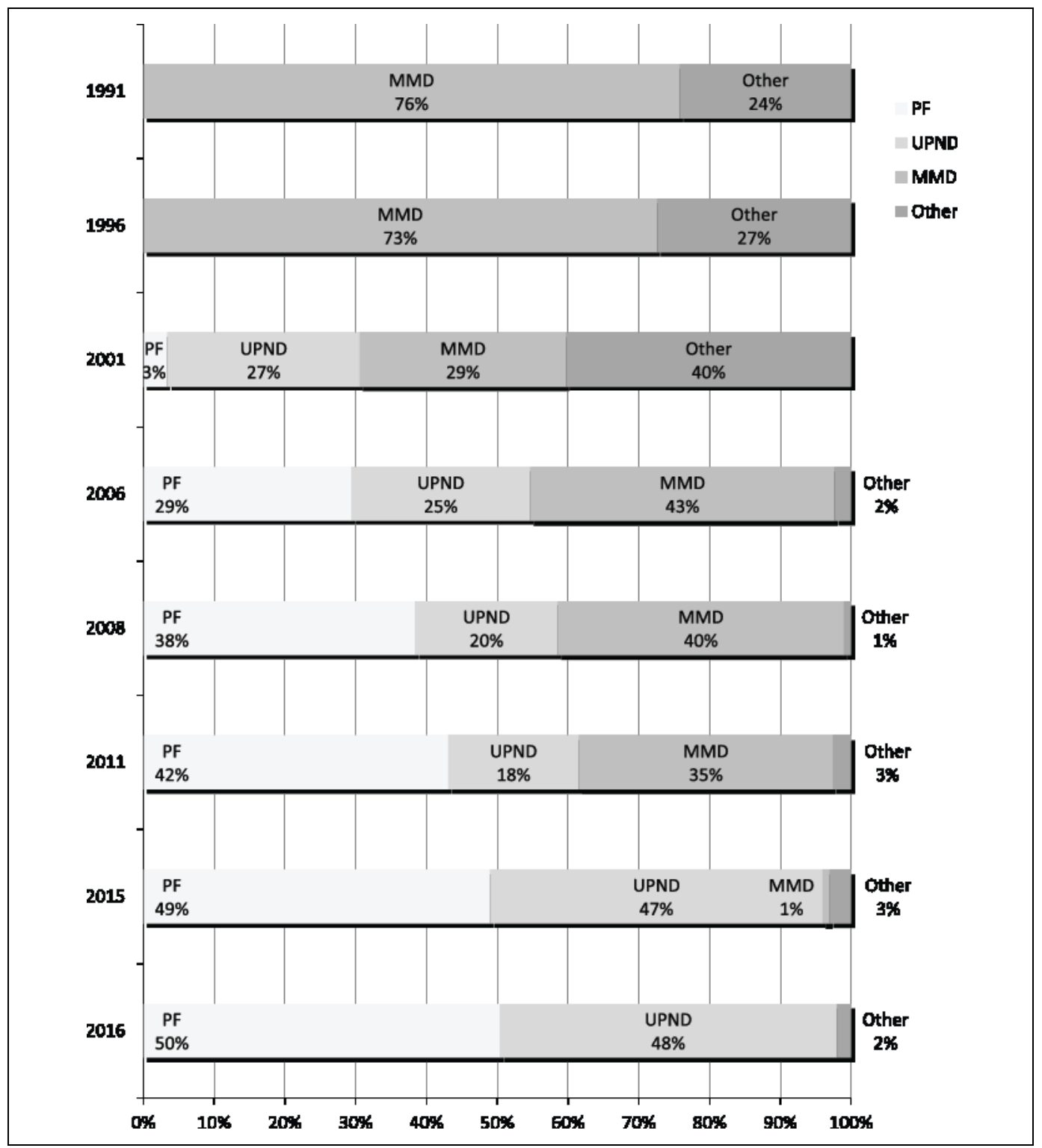

Figure 1. Party vote shares in Zambian presidential elections, 1991-2016. Source: ECZ.

trade or tenure over residences left street vendors and 'squatter' populations vulnerable in the face of politically connected protection rackets and hostile policing. Resnick describes the urban poor as unusually motivated to deploy their electoral capital to secure favourable policies. Despite their numerical dominance, she suggests that these voters had been unable to distinguish between the parties before 2006, and scattered their favours widely. Sata then emerged as a champion of the urban poor, amplifying their concerns.

Resnick surveys a range of definitions of populism, which pay attention to clientelism and charisma $(2013: 2,11)$ and she describes Sata's anti-elitist rhetoric and willingness to distribute goods 
as elements of his appeal (2013: 73-75). She also mentions aspects of political theatre, including his willingness to meet voters who visited PF headquarters, his use of bussed-in crowds at political rallies 'to convince others that he has legitimacy as the people's representative' (2013: 76) and his humiliations of senior figures (even in his own party) to create 'a paternal image that only he cared for the people' (2013: 81). Nonetheless, these insights take second place to Resnick's comparison of campaign pledges with survey data on urban residents' concerns and voting choices. Resnick's austere theoretical framework insists on identifying populism as a marketing strategy by which the PF differentiated itself, advertising 'congruence' between policy reforms and voters' interests.

Nic Cheeseman et al. (2015) work with a similar methodological toolkit but look for drivers of populism not so much in the class consciousness of informal workers as in the subjectivity of a 'populist constituency'. They suggest that, if populism is to be useful to social scientists, it ought to be definable in terms of a precise set of policies supported by populist voters. Assessing responses to Afrobarometer survey questions such as 'Should the state control agricultural credit?', they identify voter demand for intervention in economic policy as under-supplied. While recognising inconsistencies, they claim to be able to boil down Sata's policies over a decade to two essentials: state intervention and hostility to foreign investment (2015: 344). Like Resnick, Cheeseman et al. gloss significant evolutions in the PF's pitch to voters between 2006 and 2011. These explanations of 'populism' as responsiveness to durable support for state intervention or frustration over persistently unmet social needs offer few tools to explain change.

Cheeseman and Marja Hinfelaar's (2009) analysis of the evolution of the PF between 2006 and 2008 employs a better-equipped model. Drawing on Adrienne LeBas's (2006) discussion of 'polarization as craft', they argue that parties positioned themselves relative to competitors, and that the game evolved with each move. After Sata effectively politicised the terms of foreign investment and urban living standards during the 2006 campaign, the MMD tried to cut its losses in 2008 by adopting PF policies on taxing multinationals and poverty reduction. The PF responded by targeting middle class opinion formers, easing hostility towards donors, and welcoming debt relief and economic growth. Cheeseman and Hinfelaar describe this as a 'remarkable process of re-invention', in which Sata 'sold himself as a member of the political establishment', suggesting that to 'make this new approach credible to Zambian voters', he moved 'the PF towards the centre ground' (2009: 67). Given this reorientation, it is not clear why they still describe the PF as running an 'ethno-populist' campaign in 2008, falling back to a very thin definition in which any campaign partly focused on any policy (rather than simply ethnic appeals) qualifies as populist.

The difficulty for analyses grounded in policy differentiation is that all Zambian parties have been exceptionally programmatically flexible. For example, the UPND (sometimes figured as liberal) and the PF (sometimes figured as statist) have each taken, at different moments since 2001, positions on mining ranging from advocating punitive taxation or nationalisation to proposing tax and regulatory cuts. Even during the PF's populist moment in 2006, the party manifesto promised to 'Maintain an open, liberal macro-economic environment' (Patriotic Front, 2006: 26). Meanwhile, UPND newspaper advertisements proposed to 'establish grain marketing boards', 'above all subsidise agricultural production', and to establish co-operatives in a range of industries (UPND, 2006). As Cheeseman and Hinfelaar note, by 2008 the PF's rhetoric was increasingly centrist. After taking power in 2011, the policy PF ministers worked hardest to sell (delighting Western donors) was cutting agricultural, fuel and food subsidies. The UPND criticised the resulting rising cost of living and promised to reverse subsidy cuts. As the 2016 election approached, UPND leader Hichilema became at times outlandishly interventionist, proposing to re-open the one-party era car factory in Livingstone and claiming, 'we want to empower local transporters and so if there is a company from South Africa, Congo, Zimbabwe or Malawi that is transporting our maize, your days are numbered' (Lusaka Times, 2016). Hichilema's pitch at other moments was that he would run Zambia like a business. Among the party's ten-point manifesto was one (populist?) pledge to tackle inequality, and 
other (neo-liberal?) promises to create jobs 'by creating a supportive environment for business that promotes investment', and to improve competitiveness by cutting red tape (UPND, 2016).

The programmatic flexibility of Zambia's parties is reflected in the ease with which politicians rotate among them and alliances between them are made and broken. UNIP, the MMD, UPND and $\mathrm{PF}$ all featured at their births politicians defecting from senior roles in other parties, and many have since continued to circulate. An extreme example is former president Rupiah Banda. When he won the MMD's nomination in 2008, Banda was suspected of continuing to ground his influence in UNIP networks. The PF's successful campaign in 2011 was largely built on a critique of his patrimonial modus operandi. Having lost the leadership of the MMD, Banda sought to retake it just before the 2015 elections. He failed, then endorsed the PF and is now figured as a leading influence. Offering policy differentiation as the factor that links voters to Zambian politicians or parties requires very selective readings of this kind of behaviour.

Nonetheless, Cheeseman and Hinfelaar are right that something about the PF has consistently attracted urban voters. I have combined electoral commission and census data to identify 28 'urban' constituencies among Zambia's 150 parliamentary seats (these are defined as those in districts with a population density of over 100 persons per square kilometre). In 2006, the PF won the plurality of votes in all but two of these (Bwacha and Livingstone). In 2008, 2011 and 2016, only Livingstone evaded the party. In $2006,55.4 \%$ of the PF's total votes came from these 28 constituencies, as compared to $19.3 \%$ for the MMD and $16.7 \%$ for the UPND. The PF's dependence on urban votes decreased gradually at each subsequent election but still, in 2016, the UPND only won just over half as many urban votes as the PF (358,146 as against 691,494). One explanation might be that Sata's campaign in 2006 was fondly remembered: a populist dog-whistle can be heard long after it is blown. That it did so as the party's policy emphasis altered suggests that we need to look beyond policy to understand populism's appeal.

\section{Populism as political theatre}

An alternative lens is provided by Ernesto Laclau (2005 among other contributions), who describes a populism he considers typical since the end of the Cold War. Laclau argues that a range of unrelated needs (for housing, employment rights, regional devolution, clean government, etc.) cannot any longer convincingly all be represented by a demand for state socialism. Populism is then a mode of articulation that aims to construct a 'chain of equivalence' between needs on the basis that they are all being frustrated by the same thing: a distant, technocratic and/or corrupt 'power'. An antagonistic social identity of 'the people' can then be cohered through the shared attachment of diverse constituencies to an 'empty signifier', even simply the name of a politician.

Resnick describes urban populations' interests coalescing under a pre-existing common set of needs, and a resulting class awareness. This awareness might be grounded in hostility to the state, driven by what Karen Tranberg Hansen (2008) identifies as a long-running 'war' between informal street traders and the local authorities in Lusaka. Still, there are reasons to be sceptical that urban Zambians might self-identify primarily in class terms. The urban poor sometimes fight together, but also compete daily against each other, as market actors hustling for opportunities. This is not special to Zambia - a common feature of a contemporary crisis of representation is the difficulty politicians face reaching across the 'void' left by the retreat of the industrial 


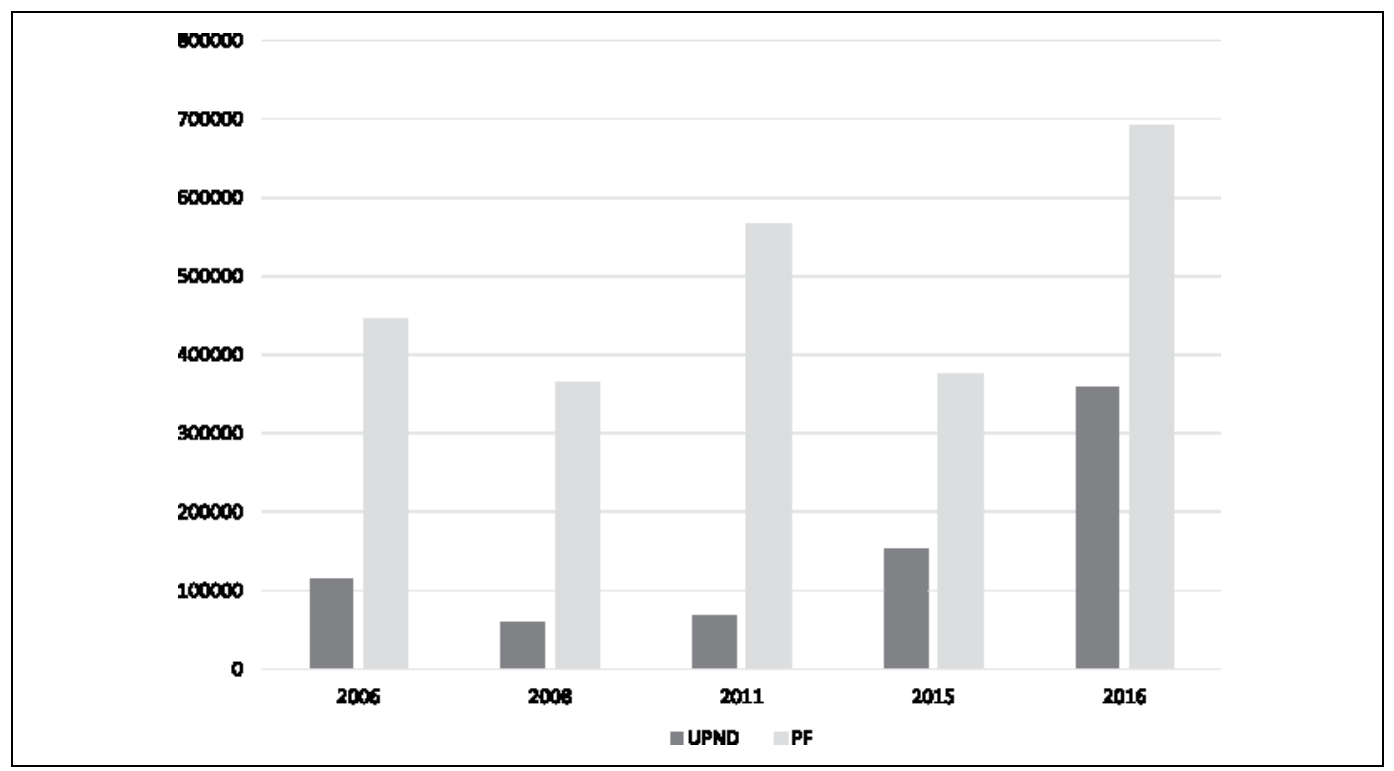

Figure 2. Votes cast for PF and UPND in Zambian presidential elections, 2006-2016 in districts with a population density over 100 persons per square kilometre.

Source: ECZ

List of constituencies: Chawama, Kabwata, Kanyama, Lusaka Central, Mandevu, Matero, Munali, Luanshya, Roan, Mufulira, Kantanshi, Kankoyo, Wusakile, Chimwemwe, Nkana, Kwacha, Kamfinsa, Chifubu, Ndola Central, Kabushi, Bwana Mkubwa, Kalulushi, Chingola, Nchanga, Chililabombwe, Livingstone, Kabwe Central, Bwacha. (2010 Census Population and Housing Preliminary Report. Vol 11, National Descriptive Tables, Central Statistics Office, Lusaka. Table 5).

working class, mass political parties and trade unions (Hay, 2007; Mair, 2006). Populism is one means of trying to remake a connection between parties and voters whose livelihoods and communities are precarious.

Larmer and Fraser (2007) argue that the PF's 2006 campaign could be understood as populist in Laclau's sense, because the PF promised to address multiple unrelated frustrations, in the name of a 'people', whose consciousness of themselves was brought into being through the theatrical construction of an 'internal boundary' between people and power. The campaign itself turned their various needs into 'fighting demands' being made against a political enemy in the name of an empty signifier: Sata.

Laclau insists that a populist signifier succeeds precisely when it is empty or universal enough to avoid any sense of favouritism among the disparate constituencies it pulls together. Nonetheless, 'emptiness' is a difficult trick to pull off, and the term gives no clues as to the charismatic elements necessary to overcome incredulity about politicians in general. Seeking precision about the forms of signifier that work, Benjamin Moffitt demands we pay attention to 'embodied, symbolically mediated performance', and to the media stages on which populists appear (2016: 3). Based on a study of 28 leaders (including Sata), Moffitt identifies three features that he claims characterise figures labelled as populist, but who offer varying policy pitches: an appeal to the people versus the elite; the deployment of bad manners to project rejection of the status quo; and the simultaneous production and exploitation of a sense of crisis or threat.

Moffitt's schema maps relatively well with Sata's initial appeal. In 2006, locked out of state media, and ridiculed by The Post, Zambia's main private newspaper, Sata sought unmediated communication with voters through call-in radio shows and campaign rallies. He jettisoned Zambian politicians' typical claims to education, rhetorical sophistication, expert knowledge and deference to traditional and religious authority. Like other contemporary African leaders described as populist, Sata dressed casually, 
used local idioms, and was seen smoking and drinking (Hart, 2014). Sata's brazen rudeness about his opponents was central to his charismatic appeal. Through his political style more than any policy platform, he communicated one message: 'your anger at those in power is legitimate; I share it' (Larmer and Fraser, 2007).

It is not obvious that, in the world's eighth most unequal country, Sata needed to produce a crisis (CIA, 2017). Nonetheless the PF's campaign challenged urban social order. Sata's celebrity increased as he faced down state authorities, enduring periodic imprisonment. During the 2006 campaign, PF supporters were equally combative, participating in riots, demonstrations and noisy assertions of a right to the streets. Inhabitants of Lusaka's peripheral neighbourhoods appeared in the city centre, bouncing and singing on the roofs of minibuses. Cadres covered bus stations in party regalia, barred MMD supporters from trading and campaigning in 'PF' markets, and at one point succeeded in diverting the presidential motorcade. 'Territorial' behaviour defined the PF's campaign. Chantal Mouffe (2005) points out that, in the deconstruction and reconstruction of antagonistic political identities - 'us' and 'them' - violence is often central.

Patience Mususa (2010) has written about one aspect of Sata's appeal that suggested his ability to exploit any crisis in urban Zambia: his promise to bring order. Sata contrasted state agencies' corruption, waste and nepotism with nostalgic references to stability provided under the one-party state. Sata thus styled himself not merely as rude but tough, and as someone who 'gets the job done'. He criticised lazy public servants and literally got his hands dirty picking up litter and inspecting work on road projects (for a Tanzanian comparison, Chachage, 2016; Collord, 2016).

We can perhaps go further with the theatrical analogy that Moffitt evokes. Populist theatre does not simply involve politicians' performing to passive, leader-worshipping masses. The bodies and voices of the audience are also brought on stage; 'the people' are encouraged to perform to themselves. The MMD's campaigns featured commissioned jingles while the PF appropriated songs and dances from folk traditions and popular musicians that were familiar to, and easily performed by, the audience (Nchindila, 2008). Official party advertising, posters and slogans dominated the MMD's campaign; homemade costumes and banners the PF's. In 2006, Sata toured FM radio studios, hearing directly from callers discussing local politics. In response, he improvised policy on the hoof, amplifying and endorsing particular concerns, drawing more and more disparate issues into a chain of equivalence. It is in this sense that it is useful to describe the party's 2006 campaign as populist. Because this was the only PF campaign of this type, it makes little sense to hold onto that description as the party's style evolved.

\section{After the populist moment - in theory}

Theorists of populism have offered only tantalising hints about what might happen in the aftermath of a populist moment. For Francisco Panizza, it is 'because it is impossible to erase the traces of the particular from the universal' that identification with an empty signifier typically fails to produce durable political movements. Rather, populist mobilisation 'generates a dialectic of aspiration, disappointment and grievances' (2005: 28). Panizza suggests three ways in which this might play out. Firstly, populist mobilisation might succeed, such that a new political settlement emerges in which previously suppressed demands and identities are included. Alternatively, a new populism might outflank the original. Finally, Panizza argues, populism might run into the ground: having engaged and mobilised popular constituencies, their disappointment may deepen cynicism, resulting in a renewed crisis of representation or generating violent identarian politics.

Laclau proposes two further alternatives. Firstly, it is possible for the 'internal boundary' (between 'people' and 'power') to be reconfigured, such that an identical set of demands is turned to a completely different political project. Alternatively, where populists take power, some demands might be met, thus undermining the chain of equivalence, resulting in an attempt to remove the 'politics' from populism (meaning its identification of an alternate future) such that each demand is 
isolated and can be engaged in the 'normal' technocratic manner. Laclau describes as especially common in post-colonial Africa, 'delivery' of some demands, combined with the repression of others and the authoritarian imposition of a discourse of national unity (2005: 47). This argument seems compatible with Panizza's third option. The following sections suggest that something like this scenario has played out in Zambia over the last decade.

\section{After a populist moment - in Zambia}

Soon after the 2006 elections, Sata's health deteriorated. When he had a heart attack in April 2008, President Mwanawasa approved a state-sponsored medical evacuation to South Africa. On his return, Sata advertised his humility, gratitude to Mwanawasa and reconciliation with the man he had mercilessly mocked in 2006. This attitude, appropriate to Zambian norms, turned out to be also strategically valuable when Mwanawasa died in August 2008 and politicians competed to embody the 'legacy' of Zambia's first dead president. His own frailty now made it implausible to present Sata as a strong man, available to the public and antagonistic to power. He presented a more sober image, emphasising his attachment to Catholic social teaching. Catholic NGOs and The Post newspaper, which had been highly critical of Sata in 2006, endorsed him, contrasting his 'simplicity' with corruption under new MMD leader, Rupiah Banda.

In 2011, even though the PF's image was softening, the incumbent MMD sought to pre-empt a repeat of the PF's 2006 challenge. On the back of an economic boom, slick television and vast billboard advertising emphasised investment in health, education and road infrastructure. At rallies, audiences were fed, clothed and entertained by hired musicians as religious, traditional and political elites mingled on stage. The relationship being theatrically acted out reflected a patrimonial bargain: the incumbent delivers 'development' through subsidies and local big men before elections, and goods during it (the MMD went as far as to hand out large numbers of branded bicycles to their activists in 2011); to mark their gratitude and loyalty, beneficiaries attend the rallies, sing praises to all involved, and expect further benefits if they provide a healthy vote (for a Senegalese comparison, including a populist backlash, see Foucher, 2007).

The MMD did not rely simply on marketing and patronage. Concerned that the PF would control urban space, they enlisted veteran political thug William Banda. Until he was eventually charged with assault, Banda targeted the same networks and territory that Sata had monopolised in 2006. 'Callboys', protected by police, physically prevented PF activists from accessing the taxi ranks, bus stations and markets, removing what few posters and flags they managed to display (Lusaka Times, 2011).

The PF's response defined the 2011 campaign as again primarily theatrical. It declared that gifts distributed by the MMD were plundered from the public. Where it would normally be a disciplinable offence for party members to consort with their opponents, the PF announced that it was acceptable for supporters to attend MMD rallies and collect these goods, but that they should break with 'tradition' and not sell their votes. The PF borrowed a slogan from a popular song; 'Donchi Kubeba?, meaning 'Don't tell them!' (that you won't be voting for the MMD). The song and a related dance became staples of PF campaign events (being reproduced in urban nightclubs and in goal celebrations for the national football team). An image of Sata holding a finger to his lips in a theatrical 'hush!', circulated during the campaign, was adopted by activists on the street. The people were constituted here by the Donchi Kubeba campaign not as a confrontational mass but as a silent majority with a shared desire to blindside the arrogant incumbents.

The PF's theatre was still themed on creating and policing a moral boundary between the people and power. However, the demands that Sata had put on the table in 2006 had been withdrawn. The PF's figurehead was visibly flagging and significantly more polite. Its urban cadres were demobilised to avoid confrontation with Banda's superior forces. The party's residual messaging was close to a 
donor-friendly 'good governance' agenda: any idea that Sata represented a radical threat depended on memories of his performance in 2006 rather than any repeat of it.

On taking power in 2011, the PF faced the challenge of meeting the hopes of both those inspired by Sata's confrontational campaign in 2006 and those happier with the conciliatory positions adopted from 2008. The administration initially delivered policies that might please both, instituting a mining tax hike and a minimum wage, bumping up civil service pay, and promising to deliver a new constitution, media liberalisation and a crackdown on corruption. Sata's first televised appearance as president, a stage-managed meeting with the Chinese ambassador, reflected the tensions that would inevitably have to be faced. Sata offered both assurances about the value of Chinese investment, and a thoroughly undiplomatic dressing down on the need for foreign investors to obey Zambian regulations. A wave of wildcat strikes on the Copperbelt in the first week of the administration pushed the contradictions. Strikes are almost impossible to declare legally in Zambia and the state had historically sided with mining companies who dismissed workers who challenged a one-sided collective bargaining arrangement. New Minister of Labour Chishimba Kambwili instead supported the right to strike and pressed the companies to settle, allowing workers to wring unprecedented pay hikes from firms unsure of their political standing. Nonetheless, the process had its limits. In February 2012, in what was one of his last confident moves, Sata responded to company concerns, criticised his 'inexperienced' Ministers and removed Kambwili's portfolio (Lusaka Times, 2012). While the PF in office rejected labour militancy, it prioritised job creation, and launched a massive bond-financed road and infrastructure programme, which provided some short term cushion against a persistent weakening of the global copper price after 2011. Nonetheless, policy responses were inconsistent and investors delayed decisions in the face of political and policy uncertainty.

The crisis that engulfed the administration almost immediately was not, however, primarily about the difficulties of pursuing policy reform, delivering on the highly contradictory PF platform or surviving adverse conditions in global markets. Sata's health was visibly fading before the party took office. In power, the management of a parliamentary minority, and resulting inter and intra-party competition was all-consuming. In particular, the succession loomed. Even during Sata's 2011 presidential inauguration, a range of other PF figures - including Sylvia Masebo, Given Lubinda and Geoffrey Bwalya Mwamba - used branded vehicles to label parts of the vast crowd as 'theirs', asserting their credentials as potential successors. Soon afterwards, rivals within the PF started to clash over the constitutionality of Guy Scott serving as vice president, given his European lineage, and over which minister should hold the instruments of power when the president was away for extended periods of medical care (Chan, 2013).

PF Secretary General Wynter Kabimba sought in vain to institutionalise a party, which in its early years made a virtue of selling no cards (membership was 'in the heart'), and to assert the secretariat's control over candidate selection. Suspicions that Kabimba was aiming at the presidency were raised by his deployment of the PF machinery to suspend rivals Mwamba and Lubinda. In the ensuing battles, cadres paraded coffins (signifying the political death of their own party's senior figures) outside State House, while Sata neither named a successor nor disciplined his bickering ministers. Having once depended on an image of openness and responsiveness to supporters and the media, and of casual dominance over his party, Sata was invisible, holding not so much as a press conference. Kabimba was eventually sacked, but Sata died relatively soon after, in October 2014, with none of the tensions in the party resolved.

During the mourning period, acting President Guy Scott and new PF Secretary General Edgar Lungu both tried and failed to fire each other. Given Sata's dominance over the party, there had never been a democratic PF convention and the procedures for finding a successor were unclear. Lungu's supporters sought to avoid a vote of party members and to secure his candidacy through nominations from MPs or Ministers, while Scott held out for a democratic conference. Scott won that battle but lost the war. At the convention itself, cadres loyal to Lungu, protected by state security, beat supporters of other candidates and barred them from entry (Africa Confidential, 2014). 
The site was too dangerous for the acting Republican President and other candidates to attend, so they convened a counter-conference nearby. While Lungu won a show of hands in an uncontested election at one venue, Miles Sampa, Sata's nephew, won a secret ballot at the other. Court cases proliferated, but, in an atmosphere of continuing violence and intimidation, none of the cases were resolved before the Scott/Sampa faction decided to 'reconcile' in the interests of national peace and Lungu was declared the PF's de facto presidential candidate.

In the 2015 presidential by-election Lungu sought to present himself as Sata's anointed successor, and said he would honour Sata simply by serving out his term without pursuing any personal vision. Lungu ducked all televised presidential hustings (as he did again in 2016) and gave just two press conferences during his first term. In 2016, Lungu's televised advertisements attempted to contrast his simple background, humility, faith, willingness to listen to (and pray with) others to resolve Zambia's economic woes with UPND leader Hichilema's business millions, alleged godlessness, and arrogance in asserting that he alone could 'fix' the economy. In terms of policy, little distinguished the candidates.

Lungu's styling fell short of anything we might sensibly describe as populist, although he was not bereft of sartorial dash, had a reputation as a drinker and was willing to sing and dance. Under the slogan 'Sonta' - meaning something like 'point at something you have done' - the PF campaign in 2016 resembled more than anything the 2011 MMD campaign, advertising an incumbent who had 'delivered' roads and infrastructure. The key difference was that Lungu's brief first term was blighted by a collapse of the copper price, an unstable currency, inflation and a drought and related energy crisis featuring extended power outages. The PF came into the 2016 elections facing a widespread perception that it had mismanaged the economy and that, soon after the election, it would have to accept an IMF loan and an associated austerity programme.

By 2016, the humiliations inflicted around the PF conferences had played themselves out. A majority of the senior figures who had contested the succession left the PF. Kabimba and Sampa launched their own parties. Sylvia Masebo, Sata's wife Christine Kaseba and her stepson Mulenga Sata all stood as candidates for the UPND, as did Guy Scott's wife Charlotte Harland. Scott and former Trade Minister Robert Sichinga publicly backed Hichilema while Mwamba became UPND Vice President. Most of these figures declared that their loyalty was to Sata, and that the PF under Lungu was unrecognisable.

Nonetheless, the UPND offered little in the way of an inspirational alternative, and Lungu narrowly 'won' a disputed election that was criticised by international observers for the persecution of the opposition and free media, and for secretive management of a contested counting process.

\section{A democracy of chameleons}

One simple answer to the question, 'how did the PF increase its vote share while its populism faded and died?' is that it avoided a free and fair contest in 2016 (European Union, 2016). 


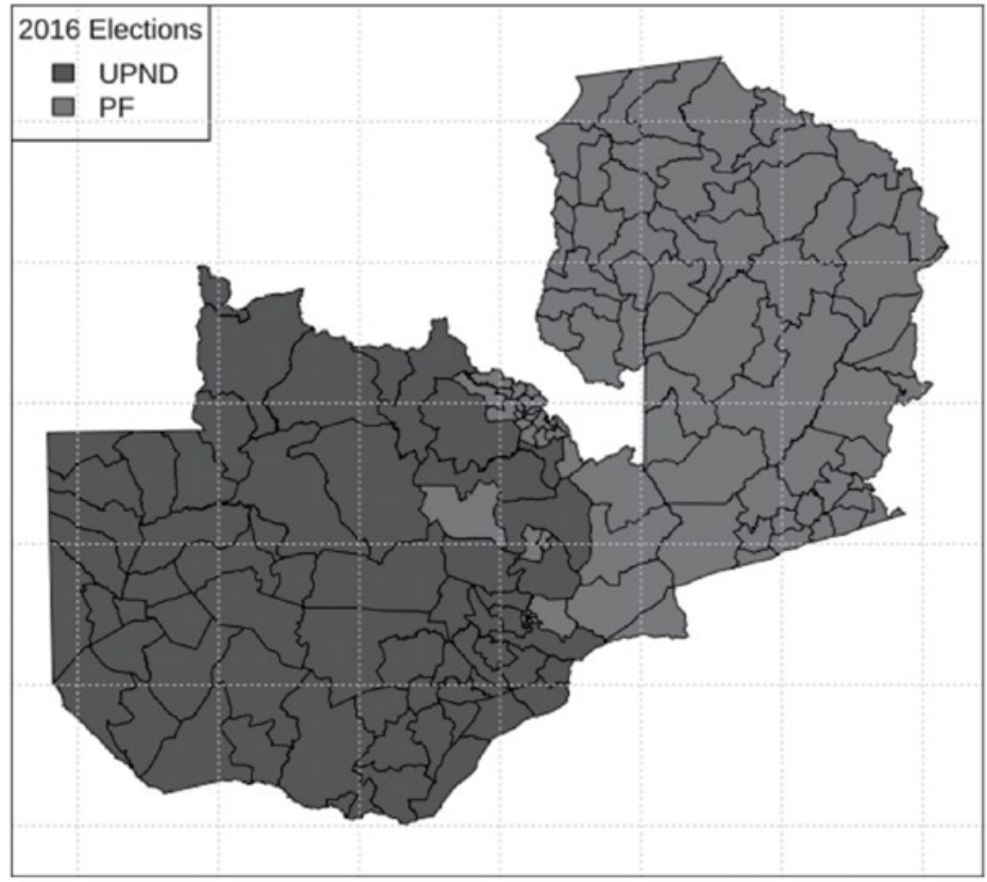

Figure 3. Geographical distribution of constituencies by political party in Zambian 2016 Legislative Elections. Source: Lighton Phiri - Own work, CC BY-SA 4.0, https://commons.wikimedia.org/w/index.php?curid=52326581.

However, to the extent that the PF vote share grew steadily after 2006, it is worth considering possible connections between populism and identity politics, and between populism and clientelism.

Resnick (2013), Cheeseman and Hinfelaar (2009), and Cheeseman and Larmer (2015) all adopt the term 'ethno-populism' in reference to the PF's growing rural support after 2006 and the increasing regional concentrations of the PF vote in the north and the east of the country. Figure 3 shows a stark regional divide that had consolidated by 2016.

This pattern is frequently described as reflecting the PF's base in a Bemba-Nyanja ethnic alliance (facing a Tonga-Lozi alliance for the UPND). Nonetheless, authors using the term ethno-populism present scant evidence about campaign messaging. Indeed, Cheeseman and Larmer row back from their initial claim that the PF blended a populist urban discourse with an ethnically exclusive rural message, noting: 'The particular emphasis in Sata's electoral messages on populist and/or ethnic discourses may have varied at times according to his audience, but it was always designed to be ethnically inclusive and to stress national, rather than sectional, concerns' (Cheeseman and Larmer, 2015: 44).

It may be that voters respond to information they glean about candidates or parties from their names or other 'cues' (Posner, 2005: 153). Nonetheless, in contemporary Zambia, the frequency with which candidates and leaders alter their affiliations complicates this task. As just described, a large share of the senior leadership of one party shifted to the other in 2016 such that the most prominent politician with a rural Northern hinterland and family connections to the Bemba Royal Establishment, Geoffrey Bwalya Mwamba, was the UPND vice-presidential candidate. As with accounts of populism that boil down to noting the urban vote share, without further primary evidence, the designation 'ethno-populism' explains little about how the PF won votes in rural areas. 
One possible explanation of the PF's ability to retain urban loyalties lies in the commonly identified link between populism and clientelism. Resnick notes that the (populist by some accounts) PRI in Mexico, 'tried to create clientelistic links with new migrants in the city slums and informal workers by offering property titles, jobs, subsidized food and housing, and licenses for vending in flea markets' (Resnick, 2013: 27). Nonetheless, she argues that while 'vote buying' is visible in Zambia, it is largely a practice of incumbent parties' rural campaigns. In urban areas, she suggests, surveillance of clients or sanction for disloyalty would be impossible, given the limited presence of membership groups representing economic interests.

Two points are worth making. Firstly, from 2006, when they won almost all urban local government elections, the PF became a form of incumbent power in the cities. Secondly, Zambia has an enduring urban culture of political organisation which may make surveillance and sanction imaginable. Under UNIP, alongside elected councillors, thousands of chairmen, secretaries and treasurers were elected as intermediaries between citizens and the party-state in residential units, agricultural co-operatives, market places, bus and taxi stands, trade unions, school councils and public works committees. These institutions atrophied and lost state sponsorship as Zambia liberalised in the 1990s. However, a bureaucratic/democratic culture, and a culture of selforganisation persist in Zambia which we might discuss in terms of what Anne Pitcher and Kelly Askew (2006) describe as 'post-socialism'. Local structures sometimes still provide a cadre of middlemen able to mobilise voters and connect them to political celebrities. They also often play a role in organising the distribution of everyday life opportunities (plots of land, market stalls and work) that Resnick describes as important in generating resentments. Clientelism, managed through micro-political structures in urban Zambia has played an important role in the ways that the PF has tried to 'deliver' to its constituents. Because these structures lack transparency and resources, they typically frustrate these hopes, generating a class of political activists full of resentment and ready to shift their allegiances (for a claim that similar dynamics fuels populism in South Africa, see Sitas, 2008).

Zambia's 'post-populist' party political scene is not best seen then either through the lens of ethnic messaging and mobilisation or through that of programmatic marketing. Rather, a set of celebrity politicians sit atop networks of cadres loyal personally to them and who travel between parties seeking opportunities for collective political advancement. Harri Englund described a 'democracy of chameleons' in late 1990s Malawi in which, while 'floor-crossing' was routinely condemned, it was also widely considered understandable that an aspirant politician, 'frustrated' in one party, might seek their fortune elsewhere (Englund, 2002).

Former Vice-President Guy Scott's account of his own (unsuccessful) attempt to reconcile with President Lungu after the 2015 elections suggests that senior political figures in Zambia understand their strategies and responsibilities this way:

I told the President [Lungu] that if you want me back, allow all Sata's people to come back. I went all the way to Western, North-Western, Copperbelt and I can't just leave them. (quoted in Mataka, 2016).

In the same interview, Scott reflected on how activists recruited to fight MMD cadres in 2011, became predatory on society, leaving gang warfare and protection rackets at the heart of the postpopulist settlement.

My other condition was 'get rid of violence' [...] I admit part of it is my fault because when I wanted William Banda out of Bauleni, I went and recruited people and say [sic] 'can you protect the people in Bauleni' but they themselves became thugs. I apologise, because they thought they were more powerful than police, so they started getting money from buses. (Mataka, 2016) 


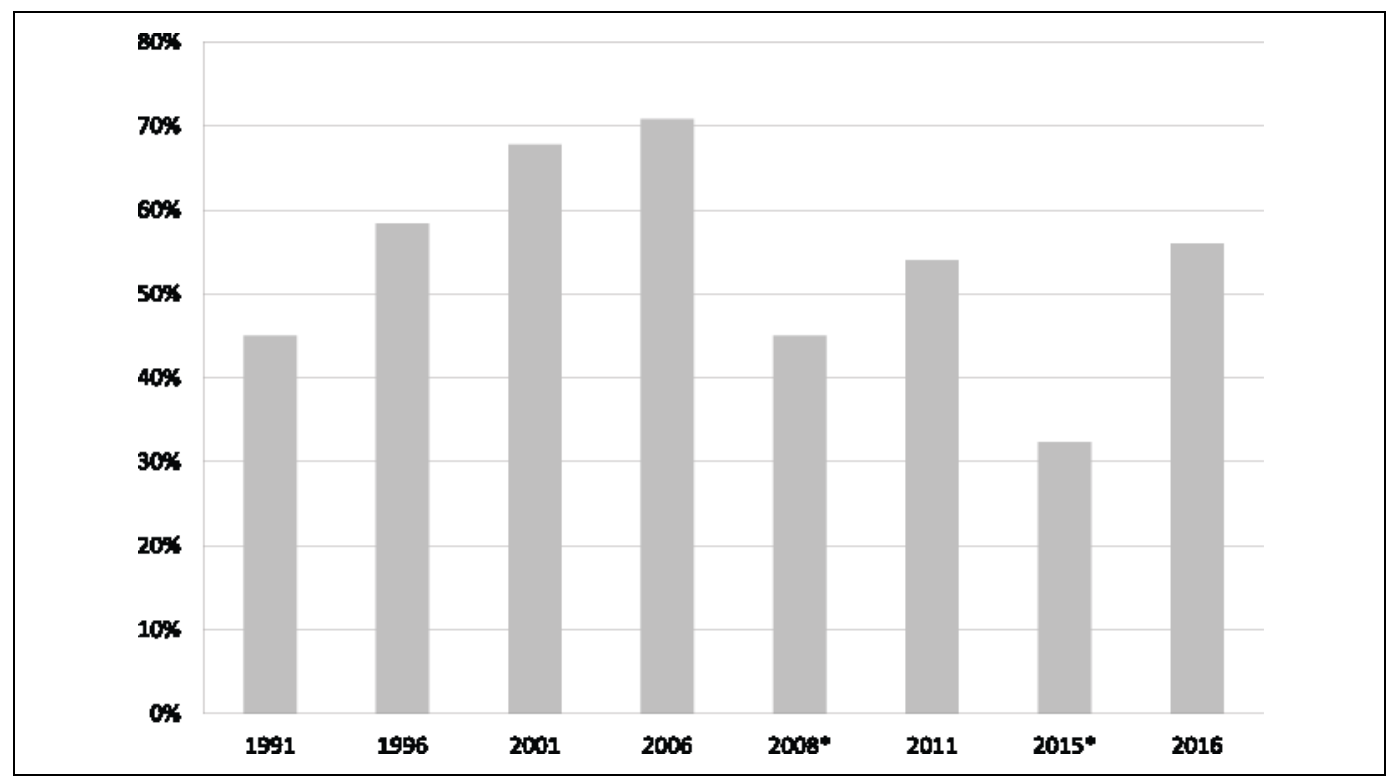

Figure 4. Share of registered voters casting ballots in Zambian presidential elections, 1991-2016. (* $=2008$ and 2015 were presidential by-elections).

Source: ECZ.

Floor-crossing and protection rackets sit at the heart of a contemporary Zambian political scene that features strikingly little expectation that politicians represent the people. While the nature of 'presidential by-elections', and the effects of voter registration exercises make comparisons imprecise, perhaps the single strongest measure of a resulting popular disillusion with politics has been the decline in voter turnout since 2006 .

\section{Conclusion}

Zambia's populist moment was centred on the vigorous personhood of Michael Sata. His claim to speak for the excluded legitimated a campaign defined not by its policy platform but a theatrical interaction with 'the people'. The challenge to authority embodied in this participatory performance enthused Zambian voters, driving record turnout. Yet the moment was short-lived. The effects bear comparison with other cases, including that of Donald Trump in the United States. Precisely because populism is an improvised performance, often tinged with violence, it rarely stabilises. The chains of equivalence that bring together multiple particular demands are fragile. Spectacles required to build the celebrity of an empty signifier can undermine that figure's credibility. Confrontations instrumental to the construction of social antagonisms simultaneously alienate. Campaigns built around a personality hostile to politics as normal may struggle to engage effectively the benefits of an institutionalised party political machine. If, in the face of these typical contradictions, populism can sustain long enough to lead to power, the daunting task of meeting the demands it legitimated looms.

Other parts of this case are more contingent. Ill, and reconciled with Mwanawasa, Sata gave up his role as an energetic tribune of the people. Because it took power at local levels before winning nationally, the PF also lost its outsider status. Once in power nationally, the PF was constantly shaken by internal tensions, and struggled to manage less favourable economic circumstances at the end of the short metals boom of 2005-2011. In trying to deliver on a promise to provide jobs, the party re-introduced significant indebtedness and, by the time of the 2016 elections, the threat of a 
return to international superintendence of Zambian policy. Candidates for the 2016 election presented difficult to distinguish agendas and none of the remaining senior politicians display the charismatic talents that might enable them to become a new 'empty signifier' to the (still) marginalised.

Yet we are not back to a technocratic square one. 'Post-populist' legacies are visible. Since the MMD's Lusaka campaign in 2011, competition among uniformed 'security details' has become a normal part of an increasingly militarised intra-party culture. The deployment of brutal methods during the PF's 2014 convention ended any sense that the party respected independent state institutions and gave a glimpse of how willing those around Lungu were to risk open conflict in order to secure their candidate. The 2016 campaign then witnessed unprecedented violence in a country that has prided itself on a peaceful political culture, resulting in the deaths of activists, and the suspension of campaign activities in two districts, including Lusaka, by the Electoral Commission (Electoral Commission of Zambia, 2016). As this article goes to press UPND leader Hichilema languishes in jail on charges of treason resulting in part from a clash between the securitised motorcades of the two main party leaders. The cadres that surround these politicians represent not voluntary, enthusiastic public engagement in a future-oriented political project, but hired thugs defending authoritarian bosses.

In Zambia's populist moment, hyper-partisanship was already present. Through confrontational political theatre Michael Sata won enthusiastic public endorsement for the idea that partisanship was a necessary radical response to corruption and inequality. Its legacy is the instrumentalisation of political violence, voter and activist intimidation, the disruption of campaign activities and a diffuse abuse of presidential power (Wahman, 2017). There is little evidence that these activities engage the voters. In this sense, we might describe the Zambian scene as 'post-populist': politicians are still keen to try on populist costumes, but the people have increasingly left them alone and insecure on the stage.

\section{Funding}

This research was supported by ESRC/DFID grant \#ES/J018945/1.

\section{References}

Africa Confidential (2014) Zambia: The PF picks two candidates, 55/24, available at: https://www.africaconfidential.com/article-preview/id/5865/The_PF_picks_two_candidates.

Chachage, Chambi (2016) What Would Populist Tananians Do? Africa Blogging, available at: http://www.africablogging.org/what-would-populist-tanzanians-do/.

Chan, Stephen (2013) Presidentialism and Vice Presidentialism in a Commonwealth Country: A cameo in Zambia. The Round Table 102(5): 431-44.

Cheeseman, Nic, Robert Ford and Neo Simutanyi (2015) Is There a 'Populist Threat' in Zambia? In Paul Collier, Christopher Adam and Michael Gondwe (eds) Zambia: Building Prosperity from Resource Wealth. Oxford University Press: 339-365.

Cheeseman, Nic and Marja Hinfelaar (2009) Parties, Platforms, and Political Mobilization: The Zambian presidential election of 2008. African Affairs 109(434): 51-76.

Cheeseman, Nic and Miles Larmer (2015) Ethnopopulism in Africa: Opposition mobilization in diverse and unequal societies. Democratization, 22(1): 22-50.

CIA (2017) Country Comparison, Distribution of Family Income, Gini Index. The World Factbook, available at: https://www.cia.gov/library/publications/the-world-factbook/rankorder/2172rank.html.

Collord, Michaela (2016) Tanzania - President Magufuli’s first months in office. Presidential Power, available at: http://presidential-power.com/?p=4642.

Electoral Commission of Zambia (2016) ECZ Suspends Campaigns in Lusaka and Nawala Districts. Press Release, 9 July. 
European Union (2016) EOM Zambia Preliminary Statement, available at: https://eeas.europa.eu/electionobservation-missions/eom-zambia-2016/8250/eu-eom-zambia-preliminary-statement-2016_en.

Englund, Harri (ed.) (2002) A Democracy of Chameleons: Politics and culture in the New Malawi. Nordic Africa Institute.

Foucher, Vincent (2007) Blue Marches: Public performance and political turnover in Senegal. In Julia C. Strauss and Donal B. Cruise O'Brien (eds) Staging Politics: Power and performance in Asia and Africa. London: IB Tauris: 111-132.

Fraser, Alastair (2016) Zambian Democracy: All heat, no light. Review of African Political Economy, available at: http://roape.net/2016/09/01/zambian-democracy-heat-no-light/.

Fraser, Alastair and John Lungu (2007) For Whom the Windfalls? Winners and losers in the privatisation of Zambia's copper mines. CSTNZ.

Hart, Gillian (2014) Rethinking the South African Crisis: Nationalism, populism, hegemony. University of Georgia Press.

Hay, Colin (2007) Why We Hate Politics. Cambridge: Polity.

Laclau, Ernesto (2005) Populism: What's in a name? In Francisco Panizza (ed) Populism and the Mirror of Democracy. London: Verso.

Larmer, Miles and Alastair Fraser (2007) Of Cabbages and King Cobra: Populist politics and Zambia's 2006 Election. African Affairs 106(425): 611-37.

LeBas, Adrienne (2006) Polarization as Craft: Explaining party formation and state violence in Zimbabwe. Comparative Politics 38(4): 419-38.

Lusaka Times (2011) Silvia Masebo Testifies in William Banda Case, available at: www.lusakatimes.com/ 2011/12/09/silvia-masebo-testifies-william-banda-case/

Lusaka Times (2012) President Sata moves Labour portfolio to Ministry of Information and Broadcasting with Immediate Effect, available at: www.lusakatimes.com/2012/02/03/president-sata-moves-labour-portfolioministry-information-broadcasting-effect/

Lusaka Times (2016) HH Promises to Revive All Dormant Industries in Livingstone Once Elected, available at: www.lusakatimes.com/2016/07/27/hh-promises-revive-dormant-industries-livingstone-elected.

Mair, Peter (2006) Ruling the Void? New Left Review 42(43): 25-51.

Mataka, Kombe (2016) Scott Explains His Support for UPND. The Post, 2 April.

Mkandawire, Thandika (1999) Crisis Management and the Making of 'Choiceless Democracies' in Africa. In Richard Joseph (eds) The State, Conflict and Democracy in Africa. Boulder: Lynne Rynner Publishers: 119-136.

Moffitt, Benjamin (2016) The Global Rise of Populism: Performance, political style, and representation. Stanford University Press.

Mouffe, Chantal (2005) On the Political. Abingdon: Routledge.

Mususa, Patience (2010) 'Getting By': Life on the copperbelt after the privatisation of the Zambia consolidated copper mines. Social Dynamics 36(2): 380-394.

Nchindila, Bernard Mwansa (2008) Honest by Chance: An investigation into Bemba music in Zambian politics. Muriki: Journal of Music Research in Africa, 5(2): 298-322.

Panizza, Francisco (2005) Introduction. In Francisco Panizza (ed) Populism and the Mirror of Democracy. London: Verso: 1-31.

Patriotic Front (2006) Patriotic Front Manifesto. Lusaka, Zambia.

Pitcher, M Anne and Kelly M Askew (2006) African Socialisms and Postsocialisms. Africa: Journal of the International African Institute 76(1): 1-14.

Posner, Daniel N (2005) Institutions and Ethnic Politics in Africa. Cambridge University Press.

Resnick, Danielle (2013) Urban Poverty and Party Populism in African Democracies. Cambridge University Press.

Simutanyi, Neo, Alastair Fraser and Nalukui Milapo (2015) Background Paper: Politics and Interactive Media in Zambia. PIMA Working Paper, University of Cambridge.

Sitas, Ari (2008) Populism and Politics in KwaZulu-Natal, Transformation, 66.

Tranberg Hansen, Karen (2008) The Informalization Of Lusaka's Economy: Regime change, ultra modern markets, and street vending, 1972-2004. In Jan-Bart Gewald and Marja Hinfelaar (eds) One Zambia, Many Histories. Leiden: Brill: 213-240. 
UPND (2006) Hakainde Hichilema for President, 'HH' The Man. UDA full-page advert in The Post, 27 September.

UPND (2016) UPND's 10 Point Plan for Zambia. Available at: http://hh-zambia.com/hhs-10-point-plan-forzambia/.

Wahman, Michael (2017) A Zambian Opposition Leader was Arrested, but there are Deeper Cracks in the Country's Democracy, The Washington Post, 18 May. 